\title{
AKTIVITAS EKSTRAK ETANOL DAUN KEREHAU (Callicarpa longifolia Lamk.) SEBAGAI ANTIDIABETES PADA MENCIT JANTAN YANG DIINDUKSI ALOKSAN
}

\author{
${ }^{1}$ Elis Susilawati, ${ }^{2}$ Nita Selifiana, ${ }^{3}$ Widhya Aligita, ${ }^{4}$ Elvania Fionna, ${ }^{5}$ Christina \\ Betharia P.S
}

\author{
1,2,3,4,5 Sekolah Tinggi Farmasi Bandung \\ J1. Soekarno Hatta No. 754 Bandung \\ email : ${ }^{1}$ elis.susilawati@stfb.ac.id
}

\begin{abstract}
ABSTRAK
Kerehau (Callicarpa longifolia Lamk.) adalah tumbuhan yang memiliki aktivitas antibakteri, antiinflamasi dan analgetik. Tetapi, belum ada yang penelitian kerehau sebagai antidiabetes. Sehingga penelitian ini bertujuan untuk menguji aktivitas antidiabetes dari ekstrak etanol daun kerehau. Metode penelitian yang digunakan adalah Tes Toleransi Glukosa Oral (TTGO) dan defisiensi insulin dengan menggunakan mencit galur swiss webster yang dikelompokkan menjadi 6 kelompok yaitu kontrol negatif, kontrol positif, pembanding (glibenklamid $0,65 \mathrm{mg} / \mathrm{KgBB})$, dosis I $(75 \mathrm{mg} / \mathrm{KgBB})$, dosis II (150 $\mathrm{mg} / \mathrm{KgBB})$, dosis III $(300 \mathrm{mg} / \mathrm{KgBB})$. Pada metode TTGO mencit diberikan glukosa monohidrat $3 \mathrm{~g} / \mathrm{KgBB}$ sebagai kontrol positif dan di ukur kadar glukosa darah setiap 30 menit selama 150 menit. Pada metode defisiensi insulin mencit dinduksi aloksan dosis 55-60 $\mathrm{mg} / \mathrm{KgBB}$. Pemberian bahan uji dilakukan selama 14 hari dan diukur kadar glukosa darah pada hari ke-7 dan ke-14. Hasil TTGO menunjukkan bahwa dosis 150 dan dosis 300 dapat menurunkan KGD pada menit ke-30. Pada defisiensi insulin semua dosis dapat menurunkan KGD pada hari ke-7. Kesimpulannya yaitu ekstrak etanol daun kerehau memiliki aktivitas antidiabetes dan dosis yang paling efektif yaitu dosis $75 \mathrm{mg} / \mathrm{KgBB}$.
\end{abstract}

Kata Kunci: Antidiabetes, defisiensi insulin, kerehau, TTGO

\begin{abstract}
Kerehau (Callicarpa longifolia Lamk.) has antibacterial, antiinflammatory and analgesic activity. However, there has been no studies of kerehau leaf as antidiabetes. So this study aimed to evaluate the antidiabetic activity of ethanol extract of kerehau leaves. The research was conducted by performing Oral Glucose Tolerance Tests (OGTT) and insulin deficiency by using swiss webster mice devided into 6 groups: negative control, positive control, standard drug control (glibenclamide $0.65 \mathrm{mg} / \mathrm{KgBW}$ ), dose I ( $75 \mathrm{mg} / \mathrm{KgBW}$ ), dose II $(150 \mathrm{mg} / \mathrm{KgBW})$, dose III (300mg / KgBW). In the OGTT method the mice were given $3 \mathrm{~g}$ / $\mathrm{KgBB}$ glucose monohydrate as a positive control and blood glucose level was measured every 30 minutes for 150 minutes. While in the method of insulin deficiency the alloxan dose for induction was $55-60 \mathrm{mg} / \mathrm{KgBW}$. treatment was performed for 14 days and blood glucose levels was measured on the 7th and 14th days. Was calculated OGTT results show that a dose of 150 and a dose of 300 might decrease blood glucose levels in 30 minute. In insulin deficiency all doses might decrease blood glucose levels by day 7 . The conclusion was that ethanol extract of kerehau leaves had antidiabetic activity and the most effective dose was $75 \mathrm{mg} / \mathrm{KgBW}$.
\end{abstract}

Keywords: Antidiabetic, insulin deficiency, kerehau, OGTT 


\section{PENDAHULUAN}

Di negara berpenghasilan tinggi, sekitar $87 \%$ sampai $91 \%$ dari semua penderita diabetes diperkirakan memiliki diabetes tipe $2,7 \%$ sampai $12 \%$ diperkirakan memiliki diabetes tipe 1 dan $1 \%$ sampai $3 \%$ memiliki jenis diabetes lainnya. Sekitar $79 \%$ tinggal di negara berpenghasilan rendah dan menengah. Jumlah penderita diabetes meningkat menjadi 451 juta jika umurnya bertambah hingga 18-99 tahun. Jika tren ini berlanjut, pada tahun 2045, 693 juta orang berusia 18-99 tahun, atau 629 juta orang 20-79 tahun, akan menderita diabetes. (International Diabetes Federation, 2017).

Salah satu tumbuhan tradisional yang dimanfaatkan oleh suku asli Kalimantan yaitu suku dayak tunjung adalah daun kerehau (Callicarpa longifolia Lamk.) (Novadiana dkk, 2014). Tumbuhan kerehau sudah digunakan oleh masyarakat dayak dan kutai sebagai obat empiris untuk mengobati bengkak, nyeri pasca persalinan, dan digunakan sebagai bedak untuk jerawat dan memiliki aktivitas antioksidan (Semiawan dkk, 2015). Selain itu daun kerehau memiliki aktivitas penyembuhan luka (Susilawati dkk, 2018). Berdasarkan penelitian sebelumnya, daun kerehau mengandung flavonoid, tanin, kuinon, terpenoid dan saponin (Supriningrum dan Junaid, 2016). Flavonoid sendiri dapat meningkatkan sekresi insulin melalui regenerasi sel $\beta$ pankreas (Marella, 2017). Sehingga berdasarkan latar belakang di atas tujuan dari penelitian ini untuk melihat potensi ekstrak etanol daun kerehau terhadap penurunan kadar glukosa darah dan sebagai antidiabetes.

\section{METODE PENELITIAN}

\subsection{Alat}

Alat yang digunakan selama penelitian adalah alat maserasi, rotary evaporator, spuit, timbangan analitik, sonde oral, tempat makan minum hewan uji, kandang hewan, alat-alat gelas, sarung tangan, alat bedah, penangas air, glukometer dan strip tes glukosa Easy Touch $^{\circledR}$.

\subsection{Bahan}

Bahan yang digunakan dalam penelitian ini adalah daun kerehau (Callicarpa longifolia Lamk.) yang diperoleh dari daerah Kalimantan, etanol 96\%, aquadest, aloksan, glibenklamid, $\mathrm{NaCl}$ fisiologis $(0,9 \%)$ dan $\mathrm{Na}-\mathrm{CMC}$ (Carboxy Methyl Cellulose) 0,5\%, pakan hewan, aquadest, pereaksi untuk skrining fitokimia.

\subsection{Hewan Uji}

Hewan yang digunakan pada penelitian ini adalah mencit jantan galur swiss Webster, usia dua sampai tiga bulan dan berat badan 20-30 gram. Semua mencit disesuaikan dengan lingkungan sekitar selama satu minggu. 


\subsection{Metode}

Pada pengujian ini dilakukan tahapan kerja mulai dari pengumpulan bahan, determinasi tumbuhan, pengolahan bahan, karakteristik simplisia, ekstraksi, skrining fitokimia, pengujian efek ekstrak etanol daun kerehau (Callicarpa longifolia Lamk.) sebagai antidiabetes.

\section{1) Tes Toleransi Glukosa (TTGO)}

Hewan dibagi menjadi enam kelompok yaitu kontrol negatif, kontrol positif (glukosa monohidrat $3 \mathrm{~g} / \mathrm{KgBB}$ ), pembanding (glibenklamid 0,65 $\mathrm{mg} / \mathrm{KgBB}$ ), EEDK dosis $75 \mathrm{mg} / \mathrm{KgBB}$, EEDK dosis $150 \mathrm{mg} / \mathrm{KgBB}$, kelompok VI yaitu EEDK dosis $300 \mathrm{mg} / \mathrm{KgBB}$.

Pada Tes Toleransi Glukosa Oral dilakukan secara preventif dengan memberikan obat pembanding glibenklamid kemudian setelah 30 menit mencit diinduksi glukosa monohidrat

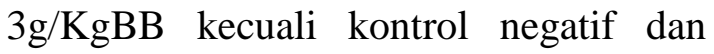
diukur kadar glukosa darah tiap 30 menit selama 150 menit.

\section{2) Defisiensi Insulin}

Hewan dibagi menjadi enam kelompok. Kelompok I yaitu kontrol negatif, kelompok II yaitu kontrol positif (aloksan monohidrat 55-60 mg/KgBB), kelompok III yaitu pembanding (glibenklamid 0,65 mg/KgBB), kelompok IV yaitu EEDK dosis $75 \mathrm{mg} / \mathrm{KgBB}$, kelompok V yaitu EEDK dosis 150 mg/KgBB, kelompok VI yaitu EEDK dosis $300 \mathrm{mg} / \mathrm{KgBB}$. Dilakukan induksi aloksan monohidrat $55-60 \mathrm{mg} / \mathrm{KgBB}$ diberikan secara intravena melalui ekor mencit pada semua kelompok kecuali kontrol negatif (-). Setelah 3 hari induksi, cek kadar glukosa darah puasa. Hewan uji dinyatakan diabetes jika kadar glukosa darah puasa $\geq 200 \mathrm{mg} / \mathrm{dl}\left(\mathrm{t}_{0}\right)$. Pemberian terapi diberikan selama 14 hari secara peroral. Pada hari ke $3\left(\mathrm{H}_{0}\right), 7\left(\mathrm{H}_{7}\right)$, dan 14( $\left.\mathrm{H}_{14}\right)$ dilakukan pengukuran kadar glukosa darah puasa.

\section{HASIL DAN PEMBAHASAN}

\subsection{Determinasi Tumbuhan}

Determinasi tumbuhan dilakukan di Laboratorium Anatomi dan Sistematika tumbuhan, Fakultas Matematika dan Ilmu Pengetahuan Alam (MIPA), Universitas Mulawarman Samarinda.

\subsection{Karakteristik Simplisia}

Karakteristik simplisia daun kerehau meliputi kadar air, kadar abu total, kadar abu tidak larut asam, kadar sari larut etanol, kadar sari larut air, dan susut pengeringan. Karakteristik simplisia merupakan suatu standarisasi yang dilakukan untuk mengetahui suatu mutu simplisia yang digunakan untuk penelitian ini. 
Tabel.1 Hasil Karakteristik Simplisia Daun Kerehau

\begin{tabular}{|l|c|c|}
\hline $\begin{array}{c}\text { Karakterisasi } \\
\text { Simplisia }\end{array}$ & $\begin{array}{c}\text { Hasil } \\
(\%) / b \\
)\end{array}$ & $\begin{array}{c}\text { Suprining } \\
\text { rum dan } \\
\text { Junaid, } \\
\mathbf{2 0 1 6} \\
(\%) b / b)\end{array}$ \\
\hline Kadar air & $8,89^{*}$ & $9,6^{*}$ \\
\hline Kadar abu total & 5,25 & 6 \\
\hline $\begin{array}{l}\text { Kadar abu tidak } \\
\text { larut asam }\end{array}$ & 0,67 & 1 \\
\hline $\begin{array}{l}\text { Kadar sari larut } \\
\text { etanol }\end{array}$ & 20 & 11,3 \\
\hline Kadar sari larut air & 17 & 17,7 \\
\hline Susut Pengeringan & 8,21 & - \\
\hline \multicolumn{2}{|r|}{$* \%$ v/b. } \\
\hline
\end{tabular}

\subsection{Skrining Fitokimia}

Skrining fitokimia bertujuan untuk mengetahui senyawa metabolit sekunder yang terkandung di dalam ekstrak etanol daun kerehau yang akan digunakan untuk penelitian. Skrining fitokimia ekstrak etanol daun kerehau meliputi alkaloid, saponin, tanin, kuinon, flavonoid, steroid/triterpenoid.
Tabel. 2 Hasil Skrining Fitokimia

Simplisia dan Ekstrak Etanol Daun

Kerehau

\begin{tabular}{|c|c|c|}
\hline $\begin{array}{c}\text { Metabolit } \\
\text { Sekunder }\end{array}$ & Hasil & $\begin{array}{c}\text { Supriningrum } \\
\text { dan Junaid, } \\
2016\end{array}$ \\
\hline Alkaloid & - & - \\
\hline Saponin & + & + \\
\hline Tanin & + & + \\
\hline Kuinon & + & + \\
\hline Flavonoid & + & + \\
\hline $\begin{array}{c}\text { Steroid/ } \\
\text { Triterpenoid }\end{array}$ & + & + \\
\hline
\end{tabular}

Keterangan :

$(-)=$ Terdeteksi

$(+)=$ Tidak terdeteksi

\subsection{Tes Toleransi Glukosa Oral}

Metode uji toleransi glukosa dilakukan sebagai uji pendahuluan untuk mengetahui kemampuan ekstrak etanol daun kerehau dalam menurunkan kadar glukosa darah terhadap mencit jantan normal setelah diinduksi dengan larutan glukosa monohidrat $3 \mathrm{~g} / \mathrm{KgBB}$.

Tabel 3. Profil Kadar Glukosa Darah Tes Toleransi Glukosa

\begin{tabular}{|l|c|c|c|c|c|c|}
\hline \multirow{2}{*}{ Kelompok } & \multicolumn{6}{|c|}{ Rata-Rata Kadar Glukosa Darah (mg/dL) menit ke- } \\
\cline { 2 - 7 } & $\mathrm{T} 0$ & $\mathrm{~T} 30$ & $\mathrm{~T} 60$ & $\mathrm{~T} 90$ & $\mathrm{~T} 120$ & $\mathrm{~T} 150$ \\
\hline $\begin{array}{l}\text { Kontrol } \\
\text { Negative }\end{array}$ & $89,3 \pm 11,8$ & $98,0 \pm 9,4^{*}$ & $85,0 \pm 11,4^{*}$ & $78,0 \pm 4,8^{*}$ & $72,3 \pm 3,3^{*}$ & $76,8 \pm 11,2^{*}$ \\
\hline $\begin{array}{l}\text { Kontrol } \\
\text { Positif }\end{array}$ & $93,5 \pm 4,9$ & $226,0 \pm 60,8$ & $154,8 \pm 27,1$ & $144,8 \pm 11,6$ & $126,5 \pm 9,5$ & $110,3 \pm 24,0$ \\
\hline $\begin{array}{l}\text { Glibenklamid } \\
0,65 \mathrm{mg} / \mathrm{Kg} \text { BB }\end{array}$ & $86,3 \pm 12,2$ & $111,5 \pm 27,7^{*}$ & $78,8 \pm 18,2^{*}$ & $63,3 \pm 9,2^{*}$ & $62,0 \pm 10,4^{*}$ & $59,5 \pm 17,7^{*}$ \\
\hline $\begin{array}{l}\text { EEDK 75 } \\
\text { mg/Kg BB }\end{array}$ & $91,0 \pm 7,5$ & $186,3 \pm 66,4$ & $154,3 \pm 48,2$ & $115,8 \pm 21,7$ & $112,5 \pm 20,7$ & $101,3 \pm 23,7$ \\
\hline $\begin{array}{l}\text { EEDK 150 mg/ } \\
\text { Kg BB }\end{array}$ & $84,5 \pm 10,1$ & $101,8 \pm 30,4^{*} *$ & $89,8 \pm 18,8^{*}$ & $91,5 \pm 33,9 *$ & $67,3 \pm 6,7^{*}$ & $67,25 \pm 14,7^{*}$ \\
\hline $\begin{array}{l}\text { EEDK 300 } \\
\text { mg/Kg BB }\end{array}$ & $81,3 \pm 4,9$ & $150,8 \pm 50,9^{*}$ & $96,5 \pm 23,6^{*}$ & $98,3 \pm 28,2 \#$ & $75,5 \pm 20,9^{*}$ & $76,8 \pm 22,3^{*}$ \\
\hline $\begin{array}{l}* \text { Berbeda bermakna (p<0,05) terhadap kontrol positif } \\
\text { EEDK = Ekstrak Etanol Daun Kerehau }\end{array}$ & & & \\
\hline
\end{tabular}




\subsection{Defisiensi Insulin}

Setelah melakukan uji pendahuluan tes toleransi glukosa terhadap ekstrak uji dan didapat hasil bahwa bahan uji dapat menurunkan kadar glukosa darah maka, selanjutnya dilakukan pengujian aktivitas antidiabetes terhadap esktrak uji menggunakan metode defisiensi insulin. Metode yang digunakan yaitu defisiensi insulin dimana pankreas tidak bisa berfungsi dengan baik memproduksi insulin karena sebagian sel $\beta$ pankreasnya rusak.

Tabel 4. Nilai Rata-Rata Kadar Glukosa Darah Pada Defisiensi Insulin

\begin{tabular}{|l|l|l|l|c|}
\hline \multirow{2}{*}{ Kelompok } & \multicolumn{2}{|c|}{ Rata-Rata Kadar Glukosa Darah (mg/dL) Hari ke- } & \multirow{2}{*}{ \% Penurunan } \\
\cline { 2 - 4 } & \multicolumn{1}{|c|}{ H0 } & H7 & H14 & $-3,23$ \\
\hline $\begin{array}{l}\text { Kontrol } \\
\text { Negatif }\end{array}$ & $92,75 \pm 5,56^{*}$ & $92,25 \pm 13,89^{*}$ & $89,75 \pm 7,63^{*}$ & 6,44 \\
\hline $\begin{array}{l}\text { Kontrol } \\
\text { Positif }\end{array}$ & $364,75 \pm 42,75$ & $370,75 \pm 24,68$ & $388,25 \pm 67,83$ & $-66,99$ \\
\hline $\begin{array}{l}\text { Glibenklamid } 0,65 \\
\text { mg/KgBB }\end{array}$ & $350,75 \pm 81,50$ & $239,25 \pm 65,88^{*}$ & $115,75 \pm 22,37 *$ & $-56,77$ \\
\hline $\begin{array}{l}\text { EEDK 75 } \\
\text { mg/KgBB }\end{array}$ & $352,25 \pm 107,71$ & $169,00 \pm 112,54^{*}$ & $152,25 \pm 123,55^{*}$ & $-61,32$ \\
\hline $\begin{array}{l}\text { EEDK 150 } \\
\text { mg/KgBB }\end{array}$ & $318,00 \pm 110,93$ & $161,00 \pm 48,56^{*}$ & $123,00 \pm 80,84^{*}$ & $-62,06$ \\
\hline $\begin{array}{l}\text { EEDK 300 } \\
\text { mg/KgBB }\end{array}$ & $383,50 \pm 110,55$ & $262,75 \pm 82,78^{*}$ & $145,50 \pm 70,82^{*}$ & \\
\hline $\begin{array}{l}* \text { Berbeda bermakna }(\mathrm{p}<0,05) \text { terhadap kontrol positif } \\
\text { EEDK = Ekstrak Etanol Daun Kerehau }\end{array}$ & & \\
\hline
\end{tabular}

Dilihat dari Tabel 4 hasil pengujian antidiabetes metode defisiensi insulin dapat diperoleh data penurunan kadar glukosa darah yang cukup bervariasi. Dari hasil statistik menggunakan metode one way anova dan dilanjutkan menggunaka Post-Hoc LSD diperoleh kelompok kontrol negatif memiliki perbedaan bermakna $(p<0,05)$ terhadap kontrol positif pada hari ketiga setelah induksi (H0) sampai hari ke-14 (H14) dan kelompok pembanding serta uji mengalami kenaikan kadar glukosa darah pada hari ketiga setelah induksi (H0) hal ini menunjukkan bahwa induksi aloksan berhasil membuat model mencit yang diabetes. Mekanisme aloksan yaitu dapat merusak pankreas secara parsial sehingga pankreas masih dapat memproduksi insulin. Aloksan selektif menghambat sekresi insulin yang diinduksi glukosa melalui penghambatan glukokinase spesifik, sensor glukosa pada sel beta yang dapat menyebabkan keadaan diabetes yang bergantung pada insulin melalui kemampuannya untuk menginduksi pembentukan spesies oksigen reaktif 
(ROS), yang menghasilkan nekrosis selektif pada sel beta. (Lenzen, 2008).

Selanjutnya, kontrol positif memiliki perbedaan bermakna dengan glibenklamid $0,65 \mathrm{mg} / \mathrm{KgBB}$. Hal ini menunjukkan bahwa metode uji adalah valid dan prosedur kerja telah dilakukan dengan benar. Adanya penurunan glukosa darah pada kelompok pembanding glibenklamid dosis $0,65 \mathrm{mg} / \mathrm{KgBB}$ disebabkan karena mekanisme kerja dari glibenklamid yaitu merangsang sekresi insulin pada sel $\beta$ pankreas yang masih bisa berfungsi memproduksi insulin.

Dilihat dari Tabel 4 ekstrak etanol daun kerehau pada dosis $75 \mathrm{mg} / \mathrm{KgBB}$, $150 \mathrm{mg} / \mathrm{KgBB}$, dan $300 \mathrm{mg} / \mathrm{KgBB}$ dapat menurunkan kadar glukosa darah secara signifikan pada hari ke-7 (H7) sampai hari ke-14 (H14) dan secara statistik memiliki perbedaan bermakna $(<0,05)$ terhadap kontrol positif hal ini menunjukkan adanya penurunkan kadar glukosa darah. Hal ini didukung pula dengan adanya data persen penurunan kadar glukosa darah dimana hasil kontrol negatif mengalami penurunan kadar glukosa darah sebesar $-3,23 \%$, sedangkan kontrol positif mengalami kenaikan kadar glukosa darah sebesar $6,44 \%$. Kemudian, kontrol pembanding mengalami penurunan kadar glukosa darah yang cukup besar yaitu $-66,99 \%$. Sedangkan pada ekstrak etanol daun kerehau dosis $75 \mathrm{mg} / \mathrm{KgBB}, \quad 150$ $\mathrm{mg} / \mathrm{KgBB}$, dan $300 \mathrm{mg} / \mathrm{KgBB}$ mengalami penurunan kadar glukosa darah berturutturut yaitu $-56,77 \%,-61,32 \%,-62,06 \%$. Dilihat dari persen penurunannya, dosis $300 \mathrm{mg} / \mathrm{KgBB}$ dapat menurunkan kadar glukosa darah yang paling besar dibandingkan dengan dosis $75 \mathrm{mg} / \mathrm{KgBB}$ dan $150 \mathrm{mg} / \mathrm{KgBB}$. Tetapi secara statistik tidak ada perbedaan bermakna $(<0,05)$ terhadap ketiga dosis tersebut sehingga dosis yang paling efektif digunakan dosis yang paling kecil yaitu dosis $75 \mathrm{mg} / \mathrm{KgBB}$.

Adanya penurunan kadar glukosa darah ini diduga adanya perbaikan sel $\beta$ pankreas yang dapat memproduksi insulin. Sehingga ekstrak etanol daun kerehau memiliki aktivitas antidiabetes. Hal ini diduga karena ekstrak etanol daun kerehau memiliki senyawa metabolit sekunder yaitu flavonoid. Dari hasil penelitian sebelumnya flavonoid memiliki aktivitas sebagai antioksidan yang dapat melindugi tubuh dari kerusakan yang disebabkan dari spesies oksigen reaktif. (Marianne, 2011). Selain itu, flavonoid sendiri mampu meregenerasi sel-sel $\beta$ pankreas sehingga defisiensi insulin dapat diatasi. (Marella, 2017). Flavonoid juga diperkirakan dapat menurunkan kadar glukosa darah dengan menghambat penyerapan glukosa dari lumen saluran cerna, terutama flavonioid yang berada dalam bentuk glikosidanya 
mempunyai gugus-gugus gula.

(Susilawati, 2017).

\section{KESIMPULAN DAN SARAN}

Berdasarkan hasil penelitian dapat disimpulkan bahwa ekstrak etanol daun kerehau dapat menurunkan kadar glukosa darah pada mencit yang diinduksi aloksan sehingga disimpulkan memiliki aktivitas sebagai antidiabetes. Dosis yang paling efektif yaitu dosis $75 \mathrm{mg} / \mathrm{KgBB}$.

\section{UCAPAN TERIMA KASIH}

Penulis mengucapkan terima kasih kepada RISTEKDIKTI yang telah memberi dukungan financial terhadap penelitian ini.

\section{DAFTAR PUSTAKA}

Semiawan F., Ahmad I., dan Masruhim MA., 2015. Aktivitas antiinflamasi ekstrak daun kerehau (Callicarpa Longifolia L.), J. Sains Dan Kesehat., 1(1): 1-4

International Diabetes Federation, 2017. IDF diabetes atlas. International Diabetes Federation, Brussels.

Lenzen S., 2008. The mechanisms of alloxan- and streptozotocin-induced diabetes. Diabetologia 51: 216-226. https://doi.org/10.1007/s00125-007-

0886-7

Marella Saritha., 2017. Flavonoids-The Most Potent Poly-phenols as Antidiabetic Agents: An Overview. Department of Nanotechnology, Acharya N.G. Ranga Agricultural University, India

Marianne, Yuandani, Rosnani, 2011. Antidiabetic Activity From Ethanol Extract Of Kluwih's Leaf (Artocarpus camansi). Jurnal Natural, 11(2).

Novadiana, Arie, dan Subur PP., 2014. "Isolasi Dan Identifikasi Senyawa Steroid Fraksi Kloroform Dari Fraksinasi Ekstrak Metanol Daun Kerehau (Callicarpa longifolia Lam)." Jurnal Kimia Mulawarman. 12(1).

Roglic, G., World Health Organization (Eds.), 2016. Global report on diabetes. World Health Organization, Geneva

Susilawati E., 2017. Aktivitas Antidiabetes Dari ekstrak Etanol Biji Hanjeli (Coix Lacryma-Jobi) Pada Mencit Galur Swiss Webster Yang Diinduksi Aloksan. J. Farm. Galen. 2(2)

Susilawati E., Aligita W., Adnyana IK., Patonah., Sukmawati, I.K., Anneesha., Putri., 2018. Activity of Kerehau (Callicarpa longifolia Lamk.) Leaves Ethanolic Extract as a Wound Healing. Journal of Pharmaceutical Sciences And Research. ISSN: 0975-1 